Access to Justice in Eastern Europe,

Issue 1 (6) 2020 10.33327/AJEE-18-3.1

ISSN 2663-0575 (Print)

ISSN 2663-0583 (Online)

http://ajee-journal.com

C H (Remco) van Rhee 'Towards

Harmonised European Rules of Civil

Procedure: Obligations of the Judge, the

Parties and their Lawyers' (2020) 1(6)

Access to Justice in Eastern Europe 6-33.

10.33327/AJEE-18-3.1-a000024

Received 01.12.2019

Revised 20.01.2019

Approved 22.01.2019

\title{
TOWARDS HARMONISED EUROPEAN RULES OF CIVIL PROCEDURE: OBLIGATIONS OF THE JUDGE, THE PARTIES AND THEIR LAWYERS
}

\author{
C.H. (Remco) van Rhee \\ Dr. habil. Professor of European Legal History \\ and Comparative Civil Procedure, Department \\ of Foundations and Methods of Law, Faculty of Law, \\ Maastricht University, Netherlands ${ }^{1 \star}$
}

doi.org/10.33327/AJEE-18-3.1-a000024

Summary: 1. Introduction - 2. General Part: Overriding Objective - 3. Management of the Procedure -4 . Determination of Facts -5 . Findings of Law -6 . Consensual dispute resolution -7 . Conclusion

\footnotetext{
$1 \quad *$ The author serves as chair of the Working group on the obligations of the judge and the parties and their lawyers established by the European Law Institute and UNIDROIT. Professor Alan Uzelac serves as co-chair. Members of the working group are professors Emmanuel Jeuland, Bartosz Karolczyk, Walter Rechberger, Elisabetta Silvestri, John Sorabji and Magne Strandberg. The draft rules and commentary below are their joint work.
} 
This article explains in detail the rules on the obligations of the judge, the parties and their lawyers in civil litigation, prepared by a working group that was established within the context of a project on European Rules of Civil Procedure of the European Law Institute and UNIDROIT. These rules are grouped into several parts devoted to the overriding objective of the proposed rules, management and planning of the proceedings, the determination of facts, findings of law, and consensual dispute resolution. The suggested rules reflect best practices in European civil procedure.

Keywords: civil litigation, obligations of the judge, obligations of the parties, obligations of lawyers, management of the proceedings, consensual dispute resolution

\section{INTRODUCTION}

The first modern attempts to harmonise rules of civil procedure in Europe date back to the 1980s. At that time, the author served as a young assistant in a project initiated by the late Professor Marcel Storme from Ghent, where representatives of the then 12 member states of the European Community (now the European Union) made attempts to develop rules of civil procedure that would be acceptable in all member states. ${ }^{2}$ Such rules are necessary given the fact that Europe does not have a system of federal courts like the United States of America. It is consequently dependent on the national courts of the member states for the correct implementation of harmonised European law, whenever legal disputes arise.

Unfortunately, the Storme project was flawed, amongst other things because rules that are acceptable to all member states are all but impossible to formulate (especially where the civil law tradition of the European continent is confronted with the common law tradition of the British Isles). If such rules can be formulated at all, they will not be very revolutionary. This is proven by the Storme Rules, for example in the very important area of evidence where the Storme Group produced few rules, one of them stating the obvious, that those who are duly summoned to court to give evidence in civil proceedings are under a duty to give evidence. ${ }^{3}$ For the Swedish law professor P.H. Lindblom, this rule and related rules were proof of the fact that the Storme Project was unsatisfactory. ${ }^{4}$ And indeed, very little has come from the rules that the Storme Group published in $1994 .^{5}$

Even though the Storme Group did not produce a set of rules that would change the civil procedural landscape in Europe, the project was important since it served to put the topic of procedural harmonisation on the European legislative agenda from the 1990s. As such, the Group inspired later attempts at harmonisation, one of them being the 2006 Principles of Transnational Civil Procedure of the American Law Institute

2 Marcel L Storme (ed), Approximation of Judiciary Law in the European Union (Kluwer \& Martinus Nijhoff 1994).

3 Storme (n 1) Art. 5.

4 PH Lindblom, 'Harmony of Legal Spheres. A Swedish View on the Construction of a Unified European Procedural Law' (1997) 5 European Review of Private Law 11-46.

5 See Storme (n 1). 
(ALI) and UNIDROIT ${ }^{6}$ which aimed at providing model rules (soft law) for the world at large. The project of the European Law Institute (ELI) and UNIDROIT focusing on the development of model rules for the member states of the European Union is another example. The results of the latter project, which started in 2013, will hopefully be published in 2020. At the time of writing, this had not yet happened.

The ELI/UNIDROIT project does not primarily aim at developing procedural rules that will be acceptable in all European member states. On the contrary, it takes best European practices as its guiding star. This means that those involved in drafting the Rules concentrate on those rules that can be qualified as 'best' from the perspective of predefined goals such as fairness, efficiency, speediness and proportionality. The project takes the relatively sophisticated 2006 Principles of Transnational Civil Procedure mentioned above as its starting point. It is felt that these Principles can serve as a source of inspiration for European rules. European rules can, however, be more elaborate and detailed than the Principles, given the fact that unlike the Principles they are not aimed at international commercial litigation globally, but at civil litigation in the relatively restricted area of the member states of the European Union.

At the time the project was initiated, it could not be expected that the United Kingdom would decide to leave the European Union and therefore the Rules also contain elements of the procedural heritage from especially England and Wales. Currently, this would not have been necessary anymore from a political perspective, but taking into consideration that English civil procedure has, in the opinion of the author, improved the quality of the new rules. Taking into consideration the common law heritage may also be beneficial for the acceptance of the Rules in the Republic of Ireland.

Although the common law influence is noticeable, many of the proposed rules find their origin in civil law jurisdictions. This means that the history of various rules can be traced back to the Romano-canonical procedure of the medieval period, i.e. the ancestor of most modern systems of civil procedure on the European Continent. ${ }^{7}$ The Romano-canonical procedure was a scholarly type of procedure, something that can for example be noted when taking into consideration its sophisticated rules on evidence. One of the aims of the Romano-canonical procedure was to avoid arbitrary judgments and for that reason rules of procedure were developed, which enhanced the chances that the final judgment would be just and based on the true facts and the correct legal basis. Consequently, the distribution of tasks amongst the various participants in the legal process (judges, parties and lawyers) was a central issue.

Traditionally, the role of the judge in the Romano-canonical procedure was more prominent than his/her role in the common law. On the Continent, the judge not only made sure that the procedural rules were observed, but he/she was also in charge of establishing the correct legal basis of the case (iura novit curia) and he/she would develop various activities in establishing the relevant facts, for example when hearing witnesses (a task that is left to the parties and their lawyers in the common law systems). Obviously,

7 See e.g. KW Nörr, Romanisch-Kanonisches Prozessrecht. Erkenntnisverfahren Erster Instanz in Civilibus (Heidelberg 2012). 
the parties and their lawyers also had far-reaching responsibilities in this respect. In the national procedures that developed since medieval times on the foundations of the Romano-canonical procedure, the division of tasks between judge and parties is still an important matter. It is therefore not a surprise that judicial activity and the division of tasks between judge and parties are also central topics where it concerns the European Rules of Civil Procedure developed within the context of the European Law Institute and UNIDROIT.

In the present contribution we will only concentrate on the role of the judge, the parties and their lawyers in the ELI/UNIDROIT Rules. Unfortunately, the final text of the Rules cannot be taken into consideration, since this text is still under preparation and has not yet been published. We will therefore focus on a text that was prepared by a working group that was established within the context of the ELI/UNIDROIT project and that is tasked with drafting the rules on the obligations of the judge, the parties and their lawyers in civil litigation. This working group is chaired by the author of the present contribution and Professor Alan Uzelac from Zagreb in Croatia. Members of the working group are Emmanuel Jeuland (France), Bartosz Karolczyk (Poland), Walter Rechberger (Austria), Elisabetta Silvestri (Italy), John Sorabji (United Kingdom) and Magne Strandberg (Norway). The text below contains the rules and parts of the explanatory notes produced by the working group. ${ }^{8}$ It is unclear to what extent the ideas of the working group will be incorporated in the final, consolidated draft of the Rules, in which all rules produced by the various working groups ${ }^{9}$ will be integrated, but it is hoped that many of our ideas will survive.

The rules developed by our working group are based on a variety of sources. The starting point are the ALI/UNIDROIT Principles of Transnational Civil Procedure, especially (but not only) Principles 11 (Obligations of the Parties and Lawyers) and 14 (Court Responsibility for Direction of the Proceeding). Furthermore, Council of Europe Recommendations (especially Recommendation No. R (84) 5 on civil procedure), case law of the Court of Justice of the European Union and the European Court of Human Rights, the Storme Project on the Approximation of Judiciary Law in the European Union, model codes such as the Codigo modelo Iberico-americano, the national laws of the Member States of the European Union and other European countries and various professional codes of conduct have been taken into consideration.

Our rules deal, as stated, with the obligations of the judge, the parties and their lawyers in civil litigation. The proposed rules use the word 'obligations' in a broad sense.

$8 \quad$ Here it should be underlined that this text has been drafted by the members of the working group jointly. The selection of the relevant parts of this text reproduced in the present contribution and the way texts have been grouped together is the responsibility of the author. Some minor textual changes in the commentary have been introduced. The text of the Rules themselves is identical to the ones submitted to the European Law Institute and UNIDROIT. Permission to make the work of the working group public was obtained at the annual conference of the European Law Institute in Vienna in September 2019. It should be noted that our draft rules are subject to modification by the working group responsible for the consolidated draft containing the rules of all working groups.

9 There are 9 working groups dealing with different procedural topics, and one structure working group. See ELI, Projects: Civil Procedure <https://www.europeanlawinstitute.eu/projects-publications/ current-projects-feasibility-studies-and-other-activities/current-projects/civil-procedure/> accessed January 2020. 
This expression encompasses both duties in the strict sense of the term (in German: Pflichten) and duties, which are only indirectly sanctioned (mere obligations, in German: Lasten). ${ }^{10}$ The focus of our rules is, however, on effectiveness: there should be both adequate means and motivations to ensure that all obligations in the proceedings are respected effectively.

Obligations may be either positive or negative. Positive obligations require actions to be undertaken in order to contribute to fair, efficient, speedy and proportionate resolution of the dispute. Negative obligations are those which require parties to ensure that they treat other participants in proceedings fairly i.e., obligations to refrain from acting in bad faith, in particular by not undertaking steps that unduly delay the proceedings or otherwise qualify as procedural abuse.

Our rules provide a modern approach to civil litigation in that they put the emphasis on loyal cooperation between the judge, the parties and their lawyers. The rules are written from the perspective that judges, parties and their lawyers have a shared responsibility in putting an end to disputes in a fair, efficient, speedy and proportionate manner, either by way of settlement or by way of a court decision based on the true facts and right law. This means that the adversarial-inquisitorial divide is intentionally avoided. The underlying idea of the proposed rules is that there is no mutually exclusive division of labour between the various participants in a civil lawsuit; there are only shared obligations. This means that apart from the parties, the court also has certain obligations regarding facts and evidence, whereas parties share the responsibility for the assessment of the pertinent legal issues with the judge. It is the duty of the lawyers to support the parties in the execution of their obligations. Lawyers' duties, however, go further than that, as they also have to observe professional duties normally found in codes of conduct, to which our rules refer, where necessary.

It should be noted that rules referring to the court (as opposed to judges) include the powers and responsibilities of all existing court structures, which ensure the good administration of justice in particular cases. Furthermore, the judges' obligations are shared by those who perform activities related to those of the court such as, for example, an amicus curiae.

The rules proposed by our working group are grouped under five headings. Part 1 is the general part and deals with the duty of loyal cooperation. All rules have to be interpreted within the context of this general duty and therefore this duty serves as a kind of overriding objective. Part 1 is followed by four specific parts, each part having a similar structure: every part contains separate rules on the obligations of the parties, their lawyers and judges, as well as a section on sanctions for the breach of procedural obligations. As a result, sanctions are mentioned in all parts of our rules. This is due to the fact that no single and uniform rules on sanctions are appropriate, as various actors and elements of the procedural obligations require various types and forms of sanctions. Sanctions can either be negative consequences as regards the manner in which the case is litigated, or positive consequences such as fines.

$10 \mathrm{CH}$ van Rhee, 'Obligations of the Parties and their Lawyers in Civil Litigation', in J Adolphsen et al (eds), Festschrift für Peter Gottwald zum 70. Geburtstag (Beck 2014) 669-679. 


\section{GENERAL PART: OVERRIDING OBJECTIVE}

Part 1 of our draft contains 4 rules: ${ }^{11}$

Rule 1. Obligations of the Parties

(1) Parties have a duty to promote the fair, efficient, speedy and proportionate resolution of their dispute. This duty includes their conduct before starting court proceedings, during all stages of litigation and, if necessary, in the stages after the proceedings. In particular, the parties are obliged to:

(i) contribute to the proper management of the proceedings;

(ii) present facts and evidence and assist in the proper determination of the facts;

(iii) assist in the determination of the applicable law;

(iv) undertake all reasonable efforts to settle disputes amicably.

(2) When dealing with the court and other parties, parties must cooperate in good faith. They must avoid any delaying tactics and refrain from procedural abuse.

(3) These obligations also apply to other interested persons, who participate in proceedings as well as they apply to parties.

Rule 2. Obligations of the Lawyers

(1) When representing parties, lawyers must act in accordance with the duty of loyal cooperation and assist the parties in observing their procedural obligations.

(2) These obligations apply accordingly to other persons who assist parties.

Rule 3. Obligations of the Court

(1) The court shall promote the fair, efficient, speedy and proportionate resolution of disputes. It is responsible for active and effective case management. Throughout proceedings it shall monitor whether parties, lawyers and other participants referred to in these Rules observe their obligations.

(2) The court shall undertake such steps as are necessary to establish and maintain procedural cooperation, prevent procedural abuse and/or avoid the negative consequences of violations of procedural obligations. Wherever appropriate, it shall promote the consensual settlement of disputes.

(3) Judges shall implement the court's obligations in individual proceedings. These obligations apply accordingly to other professionals who assist the court.

Rule 4. Sanctions

(1) Breach of the obligations referred to in these Rules are subject to sanctions.

(2) Sanctions have to be effective and proportionate. They may include:

(i) the proceedings continuing without the defaulting party's participation;

11 This part of the rules was originally drafted by Walter Rechberger and Remco van Rhee. 
(ii) negative inferences as to facts;

(iii) the right to dismiss or reject incomplete or unsubstantiated statements of a case or other procedural acts of the parties;

(iv) cost sanctions;

(v) fines;

(vi) disciplinary and other professional sanctions.

(3) Unless an order or direction specifies the contrary, sanctions imposed take effect automatically. Orders imposing sanctions may only be subject to appeal in exceptional circumstances.

(4) Sanctions may be imposed either by the court or by the relevant professional organisation.

Rule 1 uses the terms 'fair', 'efficient', 'speedy' and 'proportionate'. A precise definition of this terminology is hard to provide and may, in any event, even be dangerous. The terminology is flexible and should be interpreted in light of modern procedural standards. It should be read in the light of the procedural model that is envisaged by these rules. (1) 'Fair' includes the observance of modern procedural principles such as the duty of the parties to cooperate with each other and the court and the avoidance of manifestly ill-founded proceedings or the abuse of procedural rules for illegitimate purposes, (2) 'efficient' refers, amongst other things, to the use of resources in the least wasteful manner, (3) 'speedy' includes a time-frame which is reasonable, given the nature, value and complexity of the case, whereas (4) 'proportionate' to a certain extent covers similar grounds as the terminology 'efficient' and 'speedy' taken together. 'Proportionate' is added in order to emphasise that different types of cases may require different use of resources and time. The obligations mentioned under (a)-(d) are four important obligations, which result from the duty of the parties mentioned in this rule. Where the rules do not address the particular obligations of the parties, the requested procedural behaviour should be such that the fair, efficient, speedy and proportionate resolution of the dispute is promoted.

Parties should observe their obligations not only during litigation but even before the case is brought to court (the pre-action stage) and also after litigation e.g., in the enforcement stage or when exercising the right to use special remedies such as a request to reopen the proceedings. In the pre-action stage the parties should cooperate in such a manner that the facts and the law underpinning their dispute are stated sufficiently, that available evidence is exchanged and that sufficient settlement attempts are undertaken before court action is initiated. Obviously, sanctions for non-observance of these obligations are not available in the pre-action stage, but they may be imposed when the case actually reaches the court (cf. the English pre-action protocols). In the enforcement stage, the judgment debtor should cooperate loyally in the identification of relevant assets and also provide further assistance in order to allow enforcement to be executed in the required manner.

Rule 2 deals with the obligations of lawyers. Lawyers are the most important individuals who assist the parties and undertake actions in the proceedings on their behalf. The 
notion of 'lawyer' is not defined, but is meant in the sense of the definition provided in Council of Europe Recommendation $\operatorname{Rec}(2000) 21$ on the freedom of exercise of the profession of lawyer, where the term 'lawyer' is defined as a person qualified and authorised according to national law to: plead and act on behalf of his or her clients; to engage in the practice of law; and, to appear before the courts or advise and represent his or her clients in legal matters.

Assisting parties in the observance of their procedural obligations means, amongst other things, that lawyers should inform the parties of these procedural obligations as expressed in our rules and of the consequences of non-compliance. Lawyers should not knowingly cooperate in any non-compliance with these obligations. If necessary, they should actively promote compliance by the parties. If a party persists in being non-compliant, this may ultimately mean that a lawyer has to terminate his relationship with that party.

In addition to their obligation to assist the parties to comply with their procedural obligations, lawyers have common professional obligations that arise from various national and international codes and rules of professional ethics. These obligations may be considered to be incorporated in our rules. Obviously, where one is dealing with national codes and rules of professional ethics, differences may arise depending on the jurisdiction where the lawyer practises.

The obligation of lawyers to assist the parties to carry out their duty to contribute to the fair, efficient, speedy and proportionate resolution of disputes apply analogously as legal and professional obligations to experts appointed by the parties ('expert witnesses', where they exist), to their advisers (other than lawyers, if they exist in a particular jurisdiction) and other professionals assisting the parties, even if no rules or codes of professional ethics apply to them or if such rules or codes of conduct differ in certain respects. Court-appointed experts are addressed in Rule 3 (see below) since their obligations are analogous with the obligations of judges.

While Rule 2 principally deals with professionals who assist the parties, it should be noted that under various national jurisdictions, parties may be represented by other persons, such as close relatives, other persons whom they trust, or by consumer protection organisations, labour unions etc. To the extent that such persons do not act in a professional capacity i.e., in the course of business, they are not bound by professional rules, but they are subject to the common procedural obligation to contribute to good administration of justice.

Rule 3 deals with the obligations of the court. The court (here understood as an administrative entity), just like the parties, has a duty to promote the fair, efficient, speedy and proportionate resolution of disputes. The comments made above regarding the definition of fair, efficient, speedy and proportionate apply, mutatis mutandis, to the present rule.

The court can implement this obligation by organising work processes in such a way that sufficient time and resources are available to decide individual cases. It should also ensure that no more time and resources than are necessary or proportionate are expended on any case, so that enough time and resources are available for other cases i.e., the court should ensure that there is effective resource allocation across all cases before it. 
Moreover, the court must monitor whether other participants in the lawsuit observe their obligations. Monitoring is a continual duty in so far as the court ought to ensure that procedural obligations are observed and that voluntary compliance with the professional obligations is secured throughout the entire course of the proceedings. Of course, continual monitoring does not imply that the court needs to check the progress of the case on a daily basis. It only means that throughout the proceedings the court should establish whether procedural timetables and procedural steps and actions, which were agreed or determined by the court, are being complied with, taking appropriate enforcement action if necessary.

In individual cases the court's duties have to be implemented by individual judges or panels of judges. This is an aspect of their judicial case management function. It is suggested that, in implementing this function, judges are monitored by the court: monitoring of adequate performance of this function does not touch upon the independence and impartiality of judges in decision-making. The courts themselves could be monitored by a Council for the Judiciary or a similar body, which is independent of the Ministry of Justice.

Those other professionals who assist the court, mentioned at the end of Rule 3, may, for example, be court appointed experts, assessors, jurors etc. (to the extent that they exist and assist the court in any particular jurisdiction).

Rule 4 deals with sanctions. Sanctions are indispensable for promoting the observance of the obligations by those involved in litigation. In the text, the word 'sanction' is used in a broad sense, which includes not only fines or preclusions, but also any means resulting in negative consequences for a participant in the proceedings, if their obligations are not being fulfilled. Normally, such sanctions are not subject to appeal. Appeals shall be allowed, however, if the sanction is especially severe or if the sanction is of special significance to the case in general.

In this sense, Rule 4 mentions a series of pecuniary and non-pecuniary sanctions that may be imposed by the court or a professional organisation on parties, their lawyers and other participants to whom the duties provided in these rules apply. Sanctions for judges who do not observe their judicial case management tasks are more difficult to envisage, not least because providing for a means of recourse against such judges may result in additional delay. If such sanctions are available in a legal system, they should either be proposed or imposed by a competent court body (e.g., the president of the court) or by a body such as a Council for the Judiciary. Professional or disciplinary sanctions that can only be imposed by the respective professional organisation (bar association, body for judicial discipline) may result from the initiative of other participants in the proceeding (e.g., the court, parties or third interested parties reporting relevant conduct to a relevant organisation). They may also be taken by the respective organisation or body on its own initiative. Such sanctions, if imposed on judges, do not affect their independence, since independence should be understood as independence in deciding the substance of the dispute between the parties and not as independence in managing the case procedurally.

As far as the individual sanctions mentioned in Rule 4 are concerned, they are indicated there in a generic way and as a catalogue of possible responses to violations of procedural obligations. For instance, the right to continue and issue 
decisions without a non-participating party (option under (i)) includes various reactions to passive behaviour of a party (holding hearings in the absence of a duly summoned party; deciding individual issues or the whole case on the merits in spite of the fact that a party, duly informed and invited to supply its arguments, failed to do so). Negative inferences (option under (ii)) can lead to an unfavourable decision on the merits, while summary dismissal of submissions (option under (iii)) that are unsubstantiated or incomplete (e.g., dismissal of the statement of claim or appeal which does not contain essential elements) can save resources and speed up processing cases in which parties do not adhere to minimal procedural requirements. Cost sanctions (option under (iv)), fines (option under (v)) and disciplinary sanctions (option under (vi)) all serve to enforce procedural obligations and protect the integrity of the proceedings.

Cost sanctions can take different forms. Their precise shape depends on features of specific national justice systems and their approach to costs. They may include fines, cost shifting and augmented court fees.

\section{MANAGEMENT OF THE PROCEDURE}

Part 2 of our Rules contains 7 individual rules: ${ }^{12}$

Rule 5. Obligation to Actively Manage Court Proceedings

(1) The court must actively manage proceedings in order to promote their fair, efficient, speedy and proportionate resolution, whether by consensual settlement or by judgment. In doing so, the court must take account of the nature, value and complexity of the particular proceeding before it and of the need to give effect to its general management duty in all proceedings.

(2) The general management duty is a continuing duty, which must be carried out by the court at all stages of the proceedings. Individual case management decisions must be taken at the earliest opportunity.

(3) Parties must co-operate with each other and with the court in order to facilitate proper case management.

Rule 6. Case Management Conference

(1) In order to manage cases properly, the court may hold a case management conference at which the court may make any order necessary to manage the case properly. If requirements are met, the court must determine the claim on the merits at a case management conference or immediately thereafter.

(2) Such a hearing may be held in person, or by the use of electronic means of communication. The first case management conference shall be held as soon as possible.

Rule 7. Power to Issue Case Management Orders

12 This part of the rules was originally drafted by John Sorabji and Magne Strandberg. 
(1) The court may make any case management order on its own initiative or on application of any party. Orders may be made without a hearing or on an ex parte basis. Where orders are made by the court on its own initiative, any party may apply to the court to have the order reconsidered at a hearing.

(2) Where orders are made on an ex parte basis, the party to whom notice was not given may apply to have the order reconsidered.

Rule 8. Means of Case Management

(1) In order to further its general case management duty, the court may take any necessary step:

(i) schedule case management conferences;

(ii) set a timetable or procedural calendar;

(iii) set deadlines for the parties to take procedural steps;

(iv) determine the type and form of procedure;

(v) limit the number and length of submissions;

(vi) encourage the parties to take active steps to settle all or parts of their dispute including encouraging and where appropriate taking part in, the use of alternative dispute resolution (ADR) processes or practices (Rules 24 and 25);

(vii) determine the order in which issues should be tried, whether certain procedural or substantive issues should be decided jointly or separately, and whether the proceedings should be consolidated or split;

(viii) determine changes related to the parties to the proceedings and on participation of other interested persons in the proceedings;

(ix) consider whether a party is properly represented;

(x) require party's appearance in person or require a party's representative to be present at a court hearing or meeting;

(xi) ensure appropriate use of modern technology; or

(xii) take any other necessary step.

(2) While exercising its general management duty, the court shall manage the proceedings so that all relevant issues in the case are identified and may be decided in a complete and appropriate manner. The court may encourage the parties to identify the real issues in dispute, and discuss with them appropriate methods and steps for dealing with these issues.

(3) The court may vary any case management order, including abridging or extending the time to comply with them. Such orders are ordinarily not subject to appeal.

Rule 9. Sanctions for Lack of Cooperation Regarding Case Management

Unless a specific rule applies, in any case management order the court shall specify the sanction for non-compliance with that order or direction (Rule 4).

Rule 10. Cooperation in Issuing and Amending Case Management Orders 
(1) The parties should, ordinarily, be consulted by the court prior to issuing case management orders. The court shall encourage the parties to agree on the content of such directions.

(2) The parties shall attempt to agree to proposed case management directions. Where the parties agree to the directions, they shall inform the court at the earliest opportunity in advance of any scheduled case management conference.

(3) Ordinarily, the court will decide according to the agreement reached by the parties. In case an agreement cannot be reached within any relevant time limit, the court will issue case management directions on its own initiative. Such case management directions are not subject to appeal.

\section{Rule 11. Monitoring and Compliance}

(1) The court must monitor compliance with case management directions. In order to do so, the court and the parties will use the fastest and most practicable means of communication and appropriate means of modern technology.

(2) Parties and their legal representatives must inform the court promptly about the steps undertaken and respond promptly to any request from the court to provide information concerning compliance.

(3) A party may request that a competent authority transfer their proceedings to another judge, when there is a failure on the part of a judge to carry out the general case management duty.

(4) The parties may complain to relevant bodies for judicial conduct and discipline for investigation of alleged judicial failure to manage the case in an appropriate manner.

The above rules deal with obligations in regard to the management and planning of the proceedings. They specify that the court is responsible for active and effective case management, but this is always in cooperation with the parties. The obligation is discharged by various case management orders and activities and by continual monitoring by the court to ascertain whether the parties, the lawyers and other participants in the proceedings are carrying out their obligations. Active management of proceedings under the court's direction also includes the duty to consult the parties and, wherever possible, secure their agreement on the form, content and timing of particular steps in the proceedings. The court's duty of active case management authorises judges to encourage the parties to identify the real issues in dispute and to openly discuss with them the appropriate steps and methods for dealing with these issues. A case management conference is meant for consultations with the parties and their lawyers on such matters. In its case management decisions, the court should, according to the proposed rules, always take account of the nature, value and complexity of the particular proceedings, ensuring that procedures are proportionate to the value and importance of the case.

The court's duty of active case management is an important means to achieve the overall goal of a fair and speedy proceeding. Finding a suitable form, length and organisational structure of proceedings increases the prospect of a correct and fair result, either by judgment or settlement, being achieved and it saves time and money. Arguably, 
such a duty is in contrast with the traditional concept of the passive judge found in some European jurisdictions. Recently, this traditional concept has been replaced by procedural changes, which have given judges an active role in managing proceedings. Such a development was one of the core features of the Woolf Reforms in England and Wales. Active case management duties, under the concept of materielle Prozessleitung, have long formed a part of German and Austrian law. A trend towards the incorporation of active case management duties is also found in international procedural frameworks. While the Storme Report did not contain specific rules on active case management, such rules are explicitly dealt with in ALI-UNIDROIT Principle 14.

Case management duties may be carried out by a single judge, a number of judges jointly, or, in some jurisdictions, by the President of the Court. The duty of active case management is a continuing duty and as such it applies from the start of proceedings until their conclusion.

A case management conference is the arena where the parties may exercise their right to be heard, in particular regarding matters relevant for the organisation of the proceedings. It is also a means to facilitate party cooperation and cooperation between the parties and the judge. A case management conference can be a meeting with all parties present or a distanceed meeting where the parties participate via any sort of teleor video technology, or through any other appropriate means of instant communication permitted under the applicable court rules. In order to maintain the court's neutrality and to deal with the parties on equal footing, the court shall not allow one party to be present if the opposite party communicates over, for instance, telephone or video. A court may choose not to hold a case management conference, if it is not considered necessary. For instance, to hold a case management conference may be deemed superfluous in the light of the uncomplicated nature of the case, if the case is of low value, if the parties have already agreed on core case management issues, or if such a meeting lacks a clear objective.

The first case management conference should be held as soon as practically possible. The court may at any case management conference direct orders necessary to manage the case; a court may also be obliged to do so. If the case is sufficiently clear, the judge may determine the case on its merits at the case management conference.

The power to actively manage cases is one that must necessarily be exercised by the court either on its own initiative or on application of the parties; the former if the court is to properly exercise its general case management duty on a continuing basis, the latter if the parties are to properly exercise their duty to cooperate with the court in furthering the general duty.

There are instances where the case management hearing will not be possible or desirable. Exceptionally, case management decisions may need to be made in the absence of, and without notice to, one of the parties i.e., where the provision of notice would tend to frustrate the order sought or where it is not possible to give notice on grounds of urgency.

When the court issues a case management order without a hearing or on ex parte basis, in order to protect the parties' or the absent party's right to receive due notice the court shall schedule a hearing on notice to both parties at the first available date. In order 
to ensure, however, that court and party resources are not expended contrary to the general case management duty, the parties may inform the court if such a hearing is not considered necessary.

Decisions on case management are not binding on the court: any such decision may be modified or revoked. The parties may have a right to be heard before the court modifies any prior order to a significant extent.

Different national systems have different rules on forms and names of case management decisions. Less important case management decisions are not subject to appeal. For more important case management decisions, it is preferable that no separate (interlocutory) appeals are admissible, and that objections to such decisions can be made only within the appeal against the final decision. However, some national jurisdictions allow interlocutory appeals from the most important case management decisions (e.g., if the court has excluded a party representative having held that the party was not properly represented by the putative representative).

The parties will, ordinarily, comply with orders and directions voluntarily. Awareness of possible sanctions may however increase party compliance, or at the least reduce the prospect of non-compliance. In order to increase the effect of orders or directions, court orders should specify the consequences of non-compliance. The court has to specify the kind of sanction, for instance a fine, but is not obliged to specify the exact amount of such a sanction.

Ideally, case management decisions, even if they only deal with technical matters such as the scheduling and ordering of procedural actions, are taken in a cooperative fashion. The court must consult the parties before an order or direction is made. Consultations outside case management conferences shall normally be written, but should use the most efficient technology. The court shall encourage the parties to agree case management decisions, which means that the court has to take steps to prompt the parties to do so. The parties should make a serious effort to reach agreement. In order to save time and money, the parties must inform the court as soon as possible, if they agree on specific issues of case management. Where parties do not agree case management decisions they should, acting on their own initiative, inform the court of that fact.

As a general rule, the court should issue case management decisions in accordance with any agreement reached by the parties. However, such an agreement is not formally binding upon the court. The court may decide contrary to the parties' agreement if that is necessary to secure a fair, efficient, speedy and proportionate proceeding. In particular, the court may decide contrary to the parties' agreement, if it would tend to result in disproportionate use of the court's time and money. The court has a duty to decide on its own motion, if the parties cannot agree on case management issues and such a decision shall be taken in a fast and efficient manner. Pure case management decisions (directions), in particular, if they are made on the basis of the parties' agreement, should not be subject to appeal.

The court must monitor party compliance with its orders or directions. For communications related to case management, the court and the parties should avoid time consuming methods of communication like registered post and use faster means, 
such as central electronic filing systems which can partly automate monitoring and review. If such systems are not available, the court and the parties may communicate by informal means, such as by telephone, e-mail, etc.

A court may fail to carry out its case management duty effectively. This may occur, for instance, where the court has failed to issue any necessary case management order or if, due to its mismanagement of the case, the matter which is put before the court is not resolved within a reasonable time. Indeed, in line with the principle of loyal cooperation, the party or the parties should openly discuss the management issues with the court and stimulate it to take action. Transfer of a case to another judge and, especially, complaints to competent disciplinary bodies, are appropriate only if a court's failure to adequately manage the proceedings is of a more serious nature. It should be noted that in some countries transferring cases may be difficult due to concepts of 'natural jurisdiction' and lack of competence by the court management to transfer cases (which, still, may be inevitable if the judge is unable to continue its work e.g., due to sickness or other grounds).

\section{DETERMINATION OF FACTS}

Part 3 of the rules is devoted to the determination of facts. ${ }^{13}$ Five individual rules are proposed:

Rule 12. Obligation to Present Facts and Evidence

(1) Parties are under a duty to identify the matter in dispute as early as possible, taking into consideration the views of the other party, if these have become known to them.

(2) Parties are under the duty to present relevant facts and identify evidence in a diligent and complete way, ordinarily in their earliest statements of the case. Later presentation of facts and evidence has to be justified.

(3) Lawyers must advise their clients about these duties upon their appointment and assist them in identifying the matter in dispute as early as possible.

Rule 13. Role of the Court

(1) The court shall ordinarily consider only facts and evidence introduced by the parties. However, it may consider facts that appear from the case file or take evidence on its own motion, if it deems that, under the circumstances, it is necessary to the proper adjudication of the case.

(2) The court may amend or alter its orders regarding the taking of evidence.

Rule 14. Right to Disregard Belated Facts and Evidence

(1) The court may at its discretion disregard facts and evidence that are introduced later than the earliest possible opportunity for their introduction.

(2) Where a party presents belated facts and evidence they must bear their opponent's costs incurred as a result thereof, regardless of the outcome of the case.

This part of the rules was originally drafted by Bartosz Karolczyk. 
(3) New facts and evidence submitted without undue delay in response to matters raised by the other party shall not be considered belated.

Rule 15. Consequences of a Failure to Introduce Facts and Evidence

(1) If a party fails to substantiate its claim in time, the court may, in accordance with the applicable procedural rules, consider the claim as withdrawn or dismiss the case on procedural grounds.

(2) If a party fails to respond to the opposing party's factual allegations or evidence in time, the court may, in accordance with applicable procedural rules:

(i) issue a default judgment;

(ii) consider that the facts have been admitted wholly or partially; or

(iii) continue the proceedings and decide on the merits based on the available facts and evidence.

Rule 16. Closing the Proceedings

(1) As soon as the court is satisfied that both parties have had a reasonable opportunity to present their case, it will close the proceedings, after which no further submissions, arguments or evidence are allowed, unless, in exceptional circumstances such are requested and authorised by the court.

(2) The date of closing shall be fixed as early as possible, subject to later necessary amendments.

The presentation of facts and evidence is primarily a duty of the parties and should be effected as early as possible and preferably before the action is commenced during the pre-action phase. Facts and evidence presented after the early stages of proceedings are only allowed if justified.

Apart from the parties, the court has certain responsibilities regarding facts and evidence: the proposed rules provide that the court may consider facts that appear in the case file, even though they have not been used by the parties to build their argument, or may take evidence on its own motion, if this is necessary for the proper adjudication of the case. This position follows the tradition, common to many European jurisdictions, of allowing the court discretion to actively intervene in factual and evidentiary issues in order to eliminate injustice or an abuse of judicial proceedings. In the understanding of the drafters, these powers will be used only exceptionally. Thereafter, the court can only exceptionally request or permit additional facts and evidence necessary to clarify the respective positions of the parties.

The obligation to identify the matter in dispute as early as possible is an important part of the parties' obligation to contribute to proper case management. What is considered to be a part of that obligation varies in different legal traditions. For some traditions, it may imply the need to specify legal arguments. However, this part of the Rules deals mainly with the need to specify the facts of the dispute and evidence, which supports relevant factual statements made by the parties.

In civil litigation, the court does not search for facts. Instead, facts are submitted by the parties. However, their freedom in that regard cannot be unlimited because the 
incentives to obstruct the proceedings are too strong. In addition, while accurate factfinding is an ideal we should strive to achieve, it is not itself the goal of procedure. Indeed, procedure must also realise other values, in particular speed. Thus, parties are expected to present facts and identify evidence in a timely, diligent and complete fashion, so that the factual and evidentiary matters can be crystallised quickly and at an early stage in the proceedings.

To summarise, as fact-finding and evidence evaluation are within the exclusive domain of the court, it is only fitting that the parties must meet a certain standard of care in the presentation of procedural material to the court. In addition, assertions of fact should take into consideration the opposing views, if they were made known to the pleader. The assumption is that this should further the speedy and accurate determination of the dispute. Lawyers are expected to advise their clients about these duties, not least because failing to comply with them (either by the lawyer or the client) may give rise to negative consequences for the client. The participation of lawyers in preparing statements of claim is therefore vital.

Facts or evidence may be presented at a late stage, but the burden is on the pleader to justify the late presentation. The ultimate decision whether to admit belated facts or evidence is vested with the court.

As mentioned above, in civil litigation, the court generally does not search for facts on its own initiative, as that constitutes the exclusive domain of the parties pursuant to classic principles of procedure. Therefore, the court will in principle consider only facts and evidence introduced by the parties. Within these boundaries, however, the court can consider and rely on a material fact, if such fact appears from the material the parties have already submitted, but which is not asserted by either party. This is selfexplanatory: within the material provided by the parties the court must be allowed to take note of facts it considers material to decide the case. Still, the court should draw the parties' attention to such facts (cf. Rule 18).

In addition, the court may take evidence on its own motion if it deems that, under the circumstances, it is necessary to the proper adjudication of the case. This rule, based on judicial discretion, is common to many European countries and thus a part of the European legal tradition. It operates as a reasonable check in order to eliminate, in proper cases, judicial injustice or abuse of process by conducting fabricated proceedings. This option is not meant to be used on a broader scale. The court may need to take evidence on its own motion in matters that are important from a broader perspective e.g., where the public interest is at stake. For instance, it would typically occur if the case is about the loss of employment, loss of housing, or if it raises important non-economic interests like environmental issues. Another example could be if the party lacks competence or resources to propose or present the evidence. In cases where only the parties' interests are at stake, the right to take evidence ex officio should only be used exceptionally. As this right is optional on the part of the court, parties and their lawyers may not rely upon its existence to justify or excuse a failure on their part to secure relevant evidence.

Finally, and also in line with many European legal systems, until the judgment has been rendered, the court can amend or alter its orders regarding taking of evidence. 
Several types of sanctions are possible when the suggested rules are not observed. A powerful sanction is the court being allowed to disregard belated facts or evidence (preclusion). Thus, falling below a defined standard of care in conducting litigation creates the risk of losing the case. While this is a strong sanction, it is also relatively straightforward and creates a powerful incentive for the parties (provided they know about it) and lawyers to comply with Rule 12 . The rule is based on judicial discretion and is indeed very broad. It does not say when the court must disregard belated facts or evidence, neither does it say when the court must admit them due to exceptional or exculpatory circumstances. Obviously, the court's decision should be made known to the parties prior to issuing the judgment and should be justified. Consequently, this will require the court to resort to some sort of balancing test. This approach is also in line with the concept of the judge being the manager of the proceedings.

The court may at its discretion disregard facts and evidence that are introduced later than the earliest possible opportunity for their introduction. The earliest possible opportunity should be determined by two quintessential elements i.e., knowledge of evidence and of the disputed nature of a material fact. If a material fact is, thus, disputed and the party has knowledge of relevant evidence, it should identify that evidence to the court and the other party in order to support its position towards a disputed material fact. This is a reflection of the 'cards on the table' approach introduced in Rule 12.

New facts and evidence submitted without undue delay in response to the other party's statements and submissions are not to be considered belated. This provision reflects the inherent dynamic that exists within civil litigation.

The final section of Rule 14 assumes that belated material has been admitted or considered by the court, despite the lack of exculpatory or exceptional circumstances. Therefore, costs incurred by the other party as a consequence of such belated submission, should be paid by the party introducing the belated material, regardless of the outcome of the case.

Rule 15 authorises the court to sanction a party that has shown a considerable disregard of its procedural duties. The first section allows the court to dismiss, on procedural grounds, claims which are not sufficiently substantiated. This sanction is not automatic, and depends on judicial discretion and on any applicable provisions that define time periods. It is also up to the court to decide, if no special rules are provided, whether it will advise the claimant about its intention to consider the claim as withdrawn and allow to cure the deficiencies within a specific time. If the claim is considered to have been withdrawn, it may be resubmitted later.

The second section of Rule 15 is a summary expression of rules traditionally found in many European countries. As in many other rules, the course of action is left to the applicable procedural rules or, lacking further regulation, to the court's judgment. Thus, for instance, any lack of response to the statement of claim may result in a default judgment (i.e., the presumption that the defendant does not contest the claim arises). Secondly, any lack of response to specific facts may result in the conclusion being drawn that they have been admitted (of which the party will presumably learn from the judgment). Thirdly, the court may decide to continue with the process. In all such cases, the court will issue a decision on the merits which will finally dispose of the case. 
Rule 16 regulates closing the proceedings and, as such, it requires the court to close the proceeding after having heard the parties on the merits. This rule incorporates a classic European rule that is currently considered to be a universal element of procedure i.e., that the court should conclude the proceedings once the parties have had a reasonable opportunity to make their respective cases (by alleging facts and presenting evidence). As the Rules implement the idea of judicial case management, the date on which the proceedings will be closed i.e., the trial or trial phase of the proceedings will have finished, will have been identified early in the case management process. Thus, any possible element of surprise in this respect will be eliminated.

\section{FINDINGS OF LAW}

Part 4 of our Rules contains 4 rules: ${ }^{14}$

Rule 17. Obligation to Submit Relevant Legal Arguments

(1) Parties must present their legal arguments in reasonable detail. Where a party is not represented by a lawyer, the court shall assist the party to identify and clarify its legal arguments.

(2) Legal arguments should ordinarily be presented in the initial phase of the proceedings.

Rule 18. Rights and Duties of the Court Regarding Legal Arguments

(1) The court is responsible for determining the correct legal basis for its decision. It must evaluate parties' legal contentions appropriately. It may consider points of law on its own initiative if this is necessary for correct decision making.

(2) The court shall give each party a reasonable opportunity to submit relevant legal arguments, and to respond to legal arguments presented by the opposing party.

(3) Generally, no legal rule or principle may be invoked in the judgment on the merits unless all parties have had a reasonable opportunity to be heard thereon.

Rule 19. Right to Change or Amend Legal Arguments

(1) Parties may change or amend their legal arguments during the proceedings.

(2) After the proceedings are closed, legal arguments may be changed or amended only when authorised by the court and only if such change or amendment does not raise the need to introduce new facts or evidence.

Rule 20. Consequences of a Failure to Provide Legal Arguments

If a party is represented by a lawyer, the court may impose sanctions for failure to plead law or respond to legal allegations of the other party. These sanctions may include the dismissal of a statement of case that does not contain sufficiently detailed legal arguments.

The subject of Part 4 is findings of law. The rules provide that both the court and the parties should contribute to the determination of the correct legal basis for decision-

This part of the rules was originally drafted by Emmanuel Jeuland. 
making. Parties have an obligation to present contentions of law, something which must be done in reasonable detail. The court may consider points of law on its own initiative if this is necessary for correct decision-making.

In most European systems of civil procedure, the parties have both the right and the obligation to present their legal arguments. The level to which this is necessary is different in different jurisdictions and may also be different in different types of case (e.g., it may be stronger in commercial than family cases). Our approach is consistent with the trends, which in principle require the parties to present their contentions of law (and not to treat that as an optional element of the parties' statements and submissions). However, this does not exclude differentiated approaches for substantially different civil proceedings. What is 'reasonable detail' may depend on various circumstances e.g., whether the parties are represented by lawyers, or whether in particular cases the court has increased inquisitorial or investigative powers.

In any case, our rules do not dispense with the court's duty to know the law, nor is it inconsistent with the right and obligation of the judge to evaluate the correctness of the legal basis of the claim, as is presented by the parties and to consider points of law on its own motion. However, it is generally not sufficient to limit the parties' submissions merely to the bare presentation of facts on the expectation that the court will simply and passively identify the right legal provisions and apply them to the present case. Consequently, the old approach still influential in some jurisdictions, known under Latin saying 'da mihi factum, dabo tibi ius', is not supported in our rules, at least when parties are represented by qualified lawyers. However, where parties are not represented by lawyers, the court is obliged to act in a more active manner and to assist the parties in identifying and clarifying their legal arguments.

It seems to be universally accepted that the ultimate responsibility for the correct application of law is that of the court. Views differ regarding the court's right and duty to apply the law on its own motion or to apply a different law than the one pleaded by the parties. In Rule 18, the approach present in many European countries, known as 'iura novit curia' (the court needs to know the law and apply it to the case) is generally recognised. Namely, although (in contrast with the extreme versions of 'iura novit curia') the parties share with the court the responsibility for establishing the correct legal basis of the dispute, it is ultimately for the court to evaluate their legal contentions. In principle, the court must evaluate all of the parties' legal arguments that go to the issues in dispute i.e., those legal arguments that may have an impact on the court's decision. European legal systems differ in the form and scope of evaluation, but most systems require the evaluation of legal arguments in the grounds of the judgment. What is 'appropriate' evaluation must be understood according to the standards and requirements of the individual legal system. In any case, the court's obligation to evaluate legal arguments raised by the parties must not be used as a basis for groundless appeals, the aim of which is to protract the proceedings.

If law is not pleaded sufficiently, or if an incorrect law is pleaded, the court has the right and duty to consider some legal arguments on its own initiative and apply them to the facts of the case, if this is necessary to arrive at a correct decision. The judicial obligation to ascertain adequate legal arguments and apply them ex officio is not absolute. If parties 
are passive and have failed to plead the law in sufficient detail, they have failed to comply with their procedural obligations, and as such may be subject to sanctions if they were represented by lawyers. Appropriate sanctions would be the summary rejection of parties' claims and submissions.

Irrespective of the source of legal arguments (whether they were presented by the parties or introduced by the court), parties should be afforded an adequate opportunity to respond to them. The right to be heard should also be preserved in respect to legal arguments. No 'surprise judgments' (Überraschungsurteile - judgments on the merits that rest on an entirely new legal basis than the one reasonably expected and pleaded by the parties) may be issued.

As legal arguments presented by the parties generally do not bind the judge, there is more flexibility regarding any amendment of legal arguments in comparison with changes in factual pleading or presentation of new facts and evidence. Parties may freely change or amend their contentions of law throughout the proceedings, provided that such changes do not require the need to introduce new facts or evidence at a stage in which this is no more permitted. However, after the proceedings have closed, the parties' right to introduce new legal arguments is limited, as new contentions of law may delay the proceedings and cause additional costs. Therefore, after the proceedings have closed, the parties may change or amend their contentions of law only in so far as they are authorised to do so by the court, and only if that does not raise the need to introduce new facts or evidence.

It is to be expected that parties represented by lawyers present their legal arguments more extensively and accurately. It is the lawyers' role to assist the parties to become aware of their legal rights, and to present their views about those rights to the court. Therefore, the consequences (sanctions) for the lack of legal arguments may, particularly, be imposed on parties represented by lawyers. This rule mentions only one of the express sanctions: the power of the court to reject a statement of claim or other submission (e. g., an appeal) in case of a failure to plead law. If the law permits parties to appear unrepresented (which mostly happens in socially sensitive cases and cases of low value), summary dismissal for failure to plead the law is generally inappropriate. This rule does not contain the obligation of the court to reject claims and submissions automatically if represented parties fail to plead the law adequately (see the wording 'may impose', 'may include'). It is within judicial discretion to undertake other steps prior to this ultimate sanction. For instance, the court may fix a time limit to supplement submissions, specifying when it does so that if sufficient legal arguments are not submitted in time they will be dismissed.

\section{CONSENSUAL DISPUTE RESOLUTION}

The final part of our rules i.e., Part 5, contains 6 rules: ${ }^{15}$

Rule 21. Obligation to Cooperate in Dispute Settlement Attempts

This part of the rules was originally drafted by Alan Uzelac and Elisabetta Silvestri. 
(1) Parties must co-operate in actively seeking to resolve their dispute consensually, both before and after proceedings are initiated.

(2) Parties must take all reasonable opportunities to settle their dispute and, where that is not possible, to reduce the number of contested issues prior to adjudication.

Rule 22. Specific Obligations of the Parties in the Pre-Action Phase

(1) In the pre-action phase, the parties shall:

(i) exchange sufficient and concise details of their potential claim and defence;

(ii) clarify and, wherever possible, narrow the legal and factual issues in dispute;

(iii) sufficiently identify relevant evidence.

(2) The parties should also consider:

(i) exchanging settlement proposals or proposals for the use of appropriate dispute resolution methods; and

(ii) taking any other reasonable and proportionate steps to further the general duty of promoting consensual dispute resolution.

Rule 23. Obligations of the Lawyers Regarding the Use of ADR

(1) Lawyers must inform the parties about the availability of alternative dispute resolution methods, ensure that they use any mandatory method and encourage the use of other appropriate methods, and assist the parties in selecting the most suitable method.

(2) To the extent that lawyers participate in any alternative dispute resolution proceedings, they must act in good faith and not seek to abuse or obstruct those proceedings.

Rule 24. Duty to Facilitate Settlement Attempts and Promote Effective Use of ADR

(1) The court must facilitate settlement at any stage of the proceedings. If necessary for effective dispute resolution, it may order the parties to appear in person.

(2) Consensual dispute resolution must be specifically considered in the preparatory stage of proceedings and at case management conferences.

(3) Judges must inform the parties about the availability of court-annexed and out-ofcourt alternative dispute resolution methods whenever these are available. They may suggest or recommend the use of specific ADR methods.

(4) A judge may participate in settlement attempts, assist the parties in reaching a consensual solution and contribute to the proper drafting and transformation of a settlement agreement into a court-approved form such that it is enforceable.

Rule 25. Order to Attempt Settlement and Referral to ADR proceedings

(1) Subject to rules provided by special legislation, the court may in particular cases order the parties to:

(i) undertake one or more steps provided in Rule 22; 
(ii) attend one or more information sessions about the use of alternative dispute resolution;

(iii) participate in one or more alternative dispute resolution schemes, either alone or assisted by lawyers.

(2) The court may stay proceedings or reject parties' submissions until there has been compliance with any such order.

(3) If the law provides for a set of mandatory steps aimed at consensual dispute resolution that have to be exhausted prior to court proceedings, the court shall refer the parties to undertake such steps and stay or discontinue the proceedings. Proceedings may be resumed or reinitiated after the parties have undertaken sufficient and appropriate steps prescribed by mandatory legislation.

Rule 26. Sanctions for Breach of Obligation to Negotiate and Make Use of ADR

If one or more parties or their lawyers fail to cooperate in consensual dispute resolution, or do not discharge these obligations in good faith, the court may impose, on the parties and/or their lawyers:

(i) cost sanctions;

(ii) damages caused by delay and procedural abuse;

(iii) increased court fees;

(iv) fines;

(v) report the conduct to a professional organization.

Part 5 deals with the duty to promote consensual dispute resolution. The main rule is that parties must cooperate actively with each other in seeking to resolve their dispute consensually, both before and after proceedings have begun. The rules do not discuss specific types of consensual dispute resolution, since this was outside the mandate of the working group.

Rule 21 expresses the general approach of encouraging consensual dispute resolution. This obligation is applicable at all stages of proceedings. Emphasis is, however, put on early resolution which could make litigation unnecessary. It is expected that parties will not bring their claims before courts until they have exhausted other available dispute resolution options from direct negotiations to mediation and various other forms of ADR. The underlying assumption is that solutions which are consensual, voluntary and autonomous offer a simpler, faster and less expensive alternative to solutions imposed in a mandatory court procedure.

Autonomous methods of dispute resolution, in particular those that result in consensually accepted outcomes, enhance access to justice, offering another fair, efficient, speedy and proportionate way to resolve disputes. Even if the parties do not settle their case in its entirety, they may narrow the open issues and focus their efforts in subsequent litigation. The fulfilment of this obligation also contributes to the more economical, proportionate, use of state judiciary and its better functioning. 
The obligation to exhaust all available means alternative to civil court litigation is not absolute. Only those means that are reasonable, and that offer a fair chance of success have to be considered. Rule 21 sets the statement of principle, providing the obligation at a general level. The scope of this general obligation is further specified and explained in the rules that follow, starting with the period before proceedings are initiated and continuing with obligations in all stages after action is brought.

As the early resolution of disputes is to be preferred to litigation, it is essential that parties take active steps to explore such a possibility before commencing any litigation. The common purpose of these steps is to facilitate consensual settlement of claims, either directly, or by agreement on the use of some form of ADR. Where a settlement is not achieved, these steps may help in better management of the subsequent litigation proceedings.

Rule 22 lists two groups of steps that parties should in principle take or, at least seriously consider, in the earliest stages of their dispute and before resorting to any formal dispute resolution process. Therefore, the notion of 'pre-action phase' refers to the period after the dispute has arisen, but before the formal initiation of civil proceedings.

The three steps that have to be made are connected with the identification of the potential claims and defences, and with the clarification of legal and factual grounds upon which such claims are founded, as well as with the sufficient identification of the relevant evidence. Only a reasonably detailed presentation of the parties' eventual claims, and the identification of arguments and facts and evidence supporting them, can enable both parties to evaluate the situation, clarify all options and engage in settlement discussions. This pre-action obligation is also carried on, in a more stringent form, after proceedings are issued. The court may order parties who failed to do it before proceedings were issued to undertake one or more of the steps specified in Rule 22.

While the obligation to identify the claims and the main legal and factual arguments and evidence upon which the claims are based applies to all cases, optional steps include exchange of relevant evidence (based on agreement between the parties or applicable rules on disclosure) and exchange of proposals for settlement and/or proposals to use a particular form of dispute resolution. Any other reasonable or proportionate steps can also be considered with a view to reaching a settlement regarding outstanding claims and disputes.

The consequences of a failure to discharge specific obligations arising under our rules are subject to regulation by national legislation. In particular, a plaintiff who initiates civil proceedings without exchanging sufficient information on a prospective claim and its basis, with the defendant, may be subject to cost sanctions. The court may stay such proceedings or dismiss a parties' submissions (statement of claim or defence) until certain mandatory steps are complied with. The fulfilment of such an obligation may in certain cases also be a legal requirement for the admissibility of the subsequent civil action.

As a part of their general obligation to assist the parties in observing their procedural obligations, lawyers need to inform the parties about available ADR options (including 
mediation), encourage them to use them where appropriate and help them in the choice of the most appropriate method.

The use of $\mathrm{ADR}$ as a cost-effective and quick method of dispute resolution that enhances parties' access to justice is possible only if parties understand the respective ADR procedure and know how to participate in it. Generally, ADR methods do not require mandatory legal representation, and some of them are sufficiently simple so that parties can use them without lawyers. However, more complex matters may make the active participation of lawyers in one or more stages of the ADR proceedings indispensable. Lawyers should not, however, take exclusive control of the ADR proceedings. For the purpose of reaching settlements, it may be necessary that parties appear in person in settlement proceedings. In any case, effective ADR process requires that lawyers act in good faith. They should help parties explore and use all the potential of ADR, avoiding abuse and obstruction of these proceedings. If the latter occurs, lawyers may be subject to sanctions (either by fines, direct cost sanctions, or disciplinary liability).

Rule 24 makes a distinction between the court as an institution and the court as a tribunal i.e., as the judge(s) who deal with the case at hand. The facilitation of settlements, both in judicial and in extrajudicial proceedings (and in any combination of the two) may be a matter of broader projects that include institutional support (e.g., the organisation of settlement weeks and promotional campaigns for the use of particular ADR methods). On the other hand, the tribunal (sole judge or a panel of judges) seized with the case has a specific obligation to promote and stimulate settlement in the case at hand.

In our rules concerning the consensual resolution of disputes, the word 'settlement' is used in its general meaning, in the light of the fact that in a few legal systems a variety of terms are used to designate different forms of agreement by which a dispute can be resolved amicably, in court or out of court.

As settlement is particularly beneficial in the early stages of a dispute, this obligation particularly targets the preparatory stage of the proceedings and the case management conferences. In order to enhance the likelihood of settlement and broaden its scope, the parties may be ordered to appear in person, so that all vital issues can be discussed and agreed during settlement negotiations, without the need to postpone the process in order to obtain authorisation. The obligation, in respect of pending litigation, includes providing information about available in- and out-of-court ADR options. However, the tribunal seized with the case can go a step further - it may, assess all the circumstances, suggest or recommend the use of specific method. This can either be a court-annexed dispute resolution scheme, or some extrajudicial ADR method. However, any suggestion or recommendation is not binding on the parties.

Settlement attempts may be undertaken with the participation and facilitation of judges, either those that conduct the litigation or other judges that participate in courtannexed ADR schemes. The exact scope of judicial participation and the active role of judges in settlement attempts can vary under national rules. But, no matter whether settlement is the product of the process in which the judge participated or not, judges 
have a right to contribute to the proper drafting of the reached settlement agreement. The main purpose of the judicial involvement is to ensure that the settlement reached be enforceable. In many European countries, the involvement of judges in formulation of settlements is the requirement for recognition of settlement agreements as enforceable instruments that may be subject to direct enforcement just as final and enforceable judicial decisions, without the need to resort to litigation in case of refusal to observe the terms of such 'judicial' settlement (Prozessvergleich). The specific process in which relevant requirements are controlled (typically, compatibility with public policy and the rules on capacity to conclude a settlement) and the certification of the settlement agreement as an immediately enforceable instrument, is known as 'homologation' of settlement agreements.

While participating in settlement attempts, judges must always pay attention to the need to ensure that they are and remain independent and impartial. If, at any point, a judge's independence or impartiality is jeopardized, a replacement judge must be appointed. In general, if a settlement cannot be reached, the judges who have participated in specific ADR schemes as mediators (e.g., in the court-annexed mediation schemes) cannot be appointed to hear the same dispute in litigation.

Rule 25 goes one step further than Rule 24 and authorises the court to issue mandatory orders instructing the parties to undertake certain defined steps, attend one or more ADR information sessions or participate in one or more ADR schemes. Under paragraph 2 of this Rule, if the court order is not complied with, the sanction is either a stay of the proceedings or the rejection of a relevant submission (e.g., plaintiff's statement of claim). Other sanctions (e.g., cost sanctions) are not excluded. However, the court shall never compel or coerce settlement among the parties. The mandatory use of ADR shall not be a definite obstacle to access to court. Court-ordered or mandatory referral to ADR proceedings can prevent the parties from initiating or continuing litigation only for a defined and appropriate period of time (e.g., the case may be stayed for three months pending mandatory settlement negotiations). An exception to this is the situation in which the fulfilment of legal requirements undertaking of steps, etc. - is exclusively within the control of a party, in which case a party can be prevented from commencing or continuing litigation until it discharges its obligation. While deciding on compulsory steps, one should pay attention to the need to ensure that one or both parties do not lose their substantive rights due to rules on prescription (statute of limitations) or preclusion.

Rule 25 is drafted in a narrower way than the Rule 24 . While Rule 24 , on the facilitation of settlement attempts, applies directly and to virtually all types of cases, Rule 25, on orders and mandatory referrals to ADR, only applies 'subject to rules provided by special legislation' and 'in particular cases'. Therefore, mandatory settlement attempts and referrals to ADR are appropriate only in special situations, and subject to judicial discretion.

The right of the member states to make the use of mediation compulsory or subject to incentives or sanctions is asserted in the EU Mediation Directive, provided that obligations and limitations of such mandatory process do not prevent parties from exercising their right of access to the judicial system. The provisions of this Rule are 
consistent with this requirement, and in fact they go below the potential maximum: no blanket and automatic use of mandatory mediation or other ADR proceedings is provided herein.

Once the parties undertake the steps required by mandatory rules of law, they are in principle free to resume or reinitiate the proceedings. However, attention has to be paid to prescription periods and statute of limitations.

As in the case of other procedural obligations, a separate rule is devoted to sanctions. The rules emphasise that cooperation in attempts to settle cases voluntarily, just as cooperation in the use of ADR methods, is a procedural obligation and not just an option or an unenforceable right. The breach of this obligation is subject to sanctions. While some specific consequences of the breach of preceding rules on the use of ADR have already been defined, Rule 26 contains a catalogue of sanctions that may be imposed at the court's discretion. These sanctions may be imposed either on the parties, on their lawyers or on both parties and their lawyers, depending on the reasons and responsibility for the breach. Exceptions to this are those sanctions that the court is not authorised to issue on its own, such as disciplinary sanctions that can only be imposed by respective professional organisations. For such sanctions to be imposed, the court has the right and obligation to inform the bar association or a similar organisation. The same sanctions apply if cooperation in consensual dispute resolution and ADR procedures is discharged in bad faith.

\section{CONCLUSION}

As I have indicated in the introduction, the draft rules on the obligations of the judge and the parties and their lawyers in civil litigation, discussed in the present contribution, were developed within the context of a project initiated by the European Law Institute and UNIDROIT. It should, however, be remembered that these draft rules have not been sanctioned by either one of the two institutions yet. The draft rules will, however, be used in drafting a complete set of Rules of European Civil Procedure which will cover many additional aspects of civil litigation and which hopefully will be published in 2020. In the process of drafting these consolidated rules, the draft rules on obligations may be amended where needed. Nevertheless, since the draft rules on obligations are the result of a joint project of a group of leading experts in civil procedure from several member states of the European Union and also reflect best European practices in civil procedure, they may be worth the attention of an international audience. The working group feels that the rules presented here reflect a modern approach to civil litigation, which combines efficiency with quality, and which, if adopted in practice, would have the potential of greatly improving existing practices in a great many member states of the European Union. It should be noted that I have stressed the word potential in the previous sentence since it should always be remembered that rules alone, even rules of the highest quality, cannot change practice if unaccompanied by motivated judges and legal practitioners who will apply the rules according to the overriding objective stated in the first part of our rules. Without committed judges and legal practitioners who make sure that the parties cooperate in the manner as indicated in our rules, the best rules will be a failure. Obviously, committed judges and practitioners do not exist in 
abundant numbers in court systems that are overburdened and lacking resources, and the commitment of all can only be expected if sufficient training and time for reflection are offered while the new rules are being implemented. Unfortunately, in many jurisdictions problems exist concerning for example caseloads and the financing of the court system. Obviously, these problems need to be addressed first when introducing reforms aimed at best European practices in civil litigation. It is the conviction of the author of the present contribution that when indeed these problems are addressed, the suggested rules can serve as a major improvement of existing civil procedural practices in Europe and beyond. 